\title{
Survival of Salmonellas and Ascaris Suum Eggs in a Thermophilic Biogas Plant
}

\author{
By L. Plym-Forshell \\ Department of Animal Hygiene, Faculty of Veterinary Medicine, Swedish University of Agricultural Sciences, \\ Skara, Sweden.
}

\begin{abstract}
Plym-Forshell, L.: Survival of salmonellas and Ascaris suum eggs in a thermophilic biogas plant. Acta vet. scand. 1995, 36, 79-85. - In a continuous biogas plant, receiving manure from 200 dairy cows and 400 calves and young stock, survival of salmonellas and Ascaris suum eggs was studied. The bacteria and parasite eggs were kept in filter sacs in the manure that had a temperature of $55^{\circ} \mathrm{C}$. No viable salmonellas or Ascaris suum eggs could be found after $24 \mathrm{~h}$ in the digester.

Survival of salmonellas and Ascaris suum eggs was also studied in the manure pit where the manure was stored after digestion. The temperature in the manure pit varied between $22-27^{\circ} \mathrm{C}$. Salmonellas survived 35 but not 42 days. On day 56 , when the experiments had to be stopped, $60 \%$ of the Ascaris eggs were viable.
\end{abstract}

manure; anaerobic digestion; tenacity.

\section{Introduction}

It has been known for many years that grazing animals may be infected by salmonella bacteria if contaminated manure or sludge has been spread on the pasture (Bicknell 1972, Breer 1981, Hage \& Brest Nielsen 1977, Hess \& Breer 1975, Jack \& Hepper 1969, Linklater \& Graham 1985). It is also clear that salmonellas are transferred in infectious cycles in which waters, pastures, insects, birds and rodents play an important role in transmitting salmonellas from sludge or manure to domestic animals and man (Edel et al. 1972, 1976, 1978). Reduction or, better still, total elimination of viable salmonellas in manure and sludge is therefore important in order to break the infectious circles.

In conventionally stored liquid animal manure the survival time of salmonellas is con- siderable, especially in cattle manure (Strauch 1977). Liquid cattle manure must in summer be stored for 2 months and in winter for 5 months before most intestinal nematodes have died (Enigk 1980). In order to prevent salmonellas and parasite eggs from being spread with manure from infected herds to the environment, the manure must thus either be stored for a long time or be treated in some special way to obtain destruction of these organisms.

Anaerobic thermophilic digestion is an interesting method for treating manure. Apart from the production of biogas this treatment also gives a considerable odour-reduction when the manure is spread and may be a method to shorten the survival times of pathogenic microorganisms and hence lessen the 
health hazards and the demands on storage capacity. The aim of the experiments described here was to study survival of salmonellas and Ascaris suum eggs in a full scale thermophilic biogas plant running in normal production.

\section{Materials and methods \\ Description of the plant}

The plant received manure from 200 dairy cows and 400 calves and young stock. Fig. 1 shows a schematic drawing of the reactor. Every $24 \mathrm{~h}$, manure was pumped into the antechamber, $20 \mathrm{~m}^{3}$ in capacity, where it was heated up to process temperature, $55^{\circ} \mathrm{C}$, with hot water. Heating up the manure took $7 \mathrm{~h}$ and the manure was then pumped into the processing chamber. The volume of the processing chamber was $240 \mathrm{~m}^{3}$. The contents in the processing chamber were mixed intermittently. Digested manure was pumped from the processing chamber into a manure pit every 24th h. Immediately there-after fresh manure was again pumped into the antechamber etc. The construction of the plant was such that fresh manure could not be pumped directly to the processing chamber. The shortest possible detention time in the processing chamber was thus $17 \mathrm{~h}$, since heating up in the antechamber took $7 \mathrm{~h}$.

\section{Experiments in the processing chamber}

Salmonella Senftenberg and Salmonella Typhimurium were used as test bacteria. The strains were streaked on Brilliant Green Agar (Oxoid, CM 329) and incubated at $37^{\circ} \mathrm{C}$ for $24 \mathrm{~h}$. Two colonies from each strain were then transferred to $20 \mathrm{ml}$ of meat broth and incubated at $37^{\circ} \mathrm{C}$ for $24 \mathrm{~h}$. Following this, tenfold dilutions in sterile saline were made from the broths and from each dilution $1 \mathrm{ml}$ of broth was added to TGE-agar (Oxoid, CM 127) us- ing the pour plate method. The number of salmonellas per $\mathrm{ml}$ of broth was then determined by viable counts after $72 \mathrm{~h}$ at $30^{\circ} \mathrm{C}$. Controls from the broths, to check that no contamination had occurred, were made. Appropriate amounts of the broths to get approximately $5 \times 10^{7}$ salmonellas were then transferred to sacs made of nylon filter (Acropor ${ }^{\circledR}$, Gelman Sciences, Inc.) with a pore size of $0.45 \mu$. The filters were heat sealed. The filter sacs, with a size of $10 \times 2 \mathrm{~cm}$, were placed in a tube made of iron wire netting. The diameter of the iron wire was $0.4 \mathrm{~mm}$. The tube was $40 \mathrm{~cm}$ long, had a diameter of $5 \mathrm{~cm}$ and the holes in the net were $2 \times 2 \mathrm{~mm}$. A piece of stainless steel weighing $0.7 \mathrm{~kg}$ was put in the tube to secure that it did not float on top of the manure. The tube was closed in both ends by plastic lids.

Sampling was done after 24,48 and $72 \mathrm{~h}$. After sampling the filters were brought to the laboratory within $1 \mathrm{~h}$. At the laboratory the filter sacs were cut open and let down in $20 \mathrm{ml}$ of buffered peptone water. After incubation at $37^{\circ} \mathrm{C}$ for $18 \mathrm{~h}, 5 \mathrm{ml}$ of this preenrichment medium was transferred to $45 \mathrm{ml}$ of selenite broth (Oxoid CM 395, Oxoid L121). After incubation at $43^{\circ} \mathrm{C}$ for 24 and $48 \mathrm{~h} 10 \mu \mathrm{l}$ was streaked on the surface of a Brilliant Green Agar plate which was then incubated at $37^{\circ} \mathrm{C}$ for $24 \mathrm{~h}$. Colonies suspected to be salmonella were tested biochemically and serologically and for sensitivity against O-1-bacteriophage. Ascaris suum eggs were isolated by dissection of sexually mature worms. The contents of the distal part of 1 uterus horn were added to $5 \mathrm{ml}$ of tap water and then transferred to nylon filter sacs (Acropore ${ }^{\circledR}$, Gelman Sciences, Inc.) with a pore size of $3.0 \mu$. The contents of the distal part of the other uterus horn were kept as controls in tap water at $30^{\circ} \mathrm{C}$ for 30 days. The filters were heat sealed and placed in the same iron wire tube as the salmonella filter sacs. Sampling was done after 24,48 and $72 \mathrm{~h}$. 


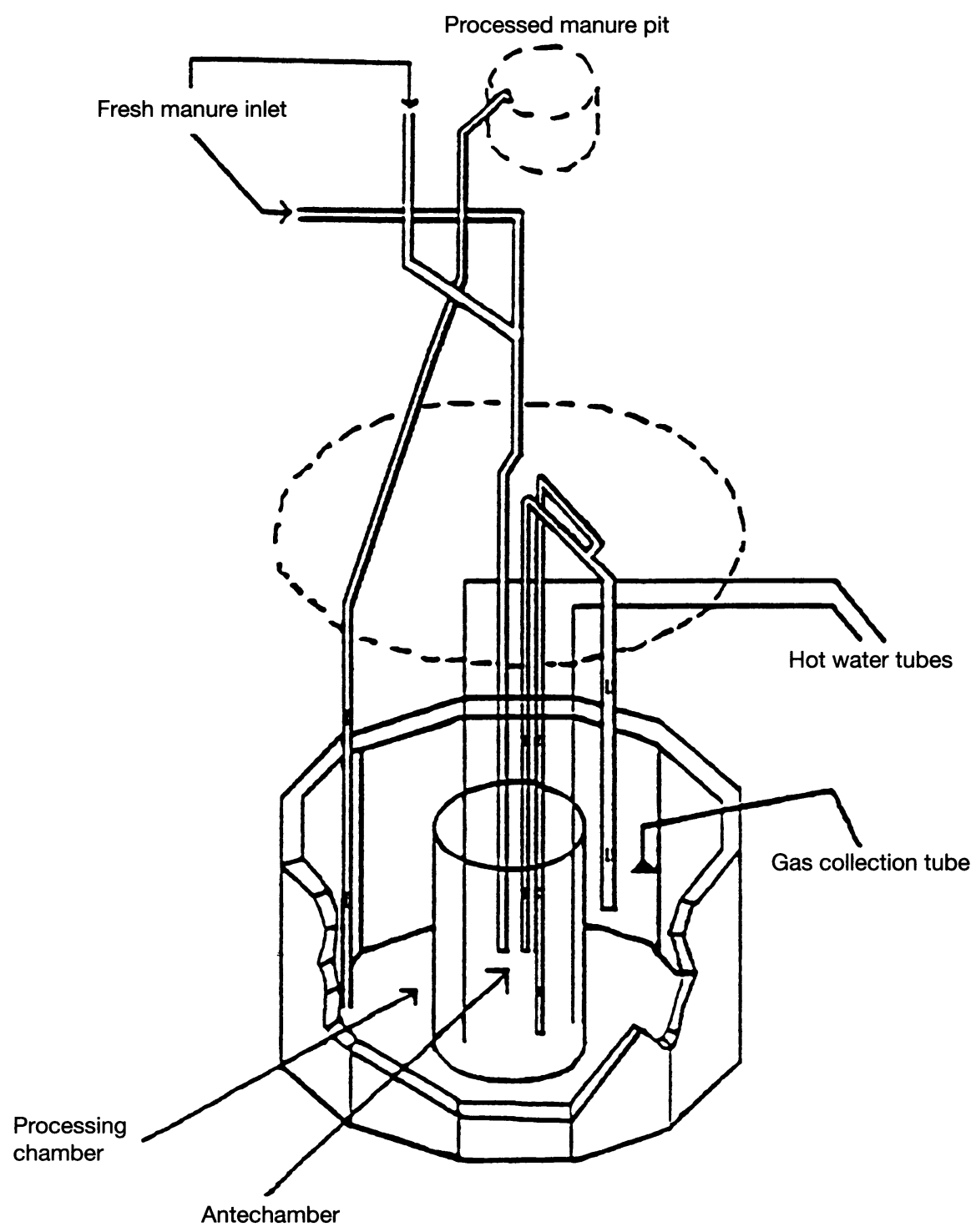

Figure 1. Schematic drawing of the reactor.

After sampling, the contents of the sacs were incubated in tap water at $30^{\circ} \mathrm{C}$ for 30 days whereupon 200 eggs were studied and the number of embryonated eggs was recorded. The experiments were repeated once.

\section{Manure pit experiments}

Similar experiments were performed in the manure pit where the digested manure was stored. Salmonella Dublin and Salmonella Typhimurium were used as test bacterias and 
Ascaris suum as test parasite. Sampling was done once a week. The temperature in the manure was recorded daily by permanent temperature sensors. Otherwise, the methods used were the same as in the processing chamber experiments.

\section{Results}

\section{Processing chamber experiments}

The manure had a dry matter content of $8.3 \%$ and a $\mathrm{pH}$ of 7.4 .

The temperature in the processing chamber varied between $53,4-55,8^{\circ} \mathrm{C}$ during the experiments. No salmonellas survived for $24 \mathrm{~h}$ in the chamber. No embryonated Ascaris eggs could be found in any experimental culture. $75-80 \%$ of the eggs kept as controls were embryonated.

\section{Manure pit experiments}

The temperature in the manure varied between $22-27^{\circ} \mathrm{C}$ during the experiments. Salmonella Dublin and Salmonella Typhimurium survived 35 but not 42 days. $75-80 \%$ of the Ascaris eggs were embryonated up to the 42 nd day. The number of embryonated eggs then declined and at day 56 about $60 \%$ were embryonated. $75-80 \%$ of the control eggs were embryonated. The experiment had to be stopped at day 56 because the pit had to be emptied.

\section{Discussion}

The results of the present experiments confirm previous reports on these topics. Salmonella bacteria are known to be relatively sensitive to moist heat. The D-value (= the heating time required to kill $90 \%$ of the bacteria at specified temperature) for Salmonella Senftenberg $775 \mathrm{~W}$, considered to be the most heat-tolerant salmonella, is $80 \mathrm{~min}$ at $55^{\circ} \mathrm{C}$
(Burge 1983). The D-value for Salmonella Senftenberg $775 \mathrm{~W}$ at $55^{\circ} \mathrm{C}$ in Heart Infusion Broth is $36.2 \mathrm{~min}$ and for a heat resistant strain of Salmonella Typhimurium $18.8 \mathrm{~min}$ (Baird Parker et al. 1970). In phosphate buffer at a pH of 7.0 Liu et al. (1968) reported D-values of Salmonella Senftenberg $775 \mathrm{~W}$ at $54.4^{\circ} \mathrm{C}$ to vary between 13 and $20 \mathrm{~min}$. Corry \& Roberts (1970) found $\mathrm{D}$-values at $55^{\circ} \mathrm{C}$ in phosphate buffer for Salmonella Typhimurium and Salmonella Dublin to be $4 \mathrm{~min}$. In nutrient broth the D-value for Salmonella Typhi and Salmonella Paratyphi at $55^{\circ} \mathrm{C}$ is $5 \mathrm{~min}$ and for Salmonella Enteritidis $5.5 \mathrm{~min}$ (Lee \& Riemann 1971). However, it must be kept in mind that the thermoresistance of pure cultures of microorganisms in broth might be, and of course often is, quite different from what is found in complex material such as manure and sludge. Many factors, biological, chemical and physical, will have a strong influence on the results.

In cattle and in pig slurry digested anaerobically at $56^{\circ} \mathrm{C}$ D-values for Salmonella Typhimurium of 10-50 min are found (Munch \& Schlundt 1983). Schlundt (1982) could not detect Salmonella Typhimurium after $6 \mathrm{~h}$ in sewage sludge digested anaerobically at $53^{\circ} \mathrm{C}$. The original concentration of Salmonella $\mathrm{Ty}$ phimurium in his study was $10^{6} / \mathrm{ml}$ sludge and the detection limit was 10 bacteria/ml. The Dvalue for salmonella varied between 0.68 $1.89 \mathrm{~h}$ with a mean of $1.07 \mathrm{~h}$. Ginnivan et al (1980) could not isolate Salmonella Dublin after $4 \mathrm{~h}$ at $55^{\circ} \mathrm{C}$ in aerobically treated pig slurry. The original concentration was $10^{6}$ Salmonella Dublin/ml slurry. The decimal decay rate was $1.8^{10} \mathrm{log} /$ hour.

Errebo Larsen \& Munch (1983) investigated the number of salmonellas in slurry from randomly selected Danish herds with unknown disease status and from herds with a known salmonella infection. The salmonella concen- 
tration was generally less than 10 cells $/ \mathrm{ml}$ slurry with $2.8 \times 10^{4} / \mathrm{ml}$ slurry being the highest recorded number. In slurry from randomly selected British pig and cattle herds occurrence of salmonellas was surprisingly frequent, but the concentrations found were low. In pig slurry $2 \times 10^{3}$ salmonella/ml was the highest observed concentration while in cattle slurry the concentrations were usually less than $1 / \mathrm{g}$ (Jones et al. 1976, Jones \& Matthews 1975). It follows that with D-values such as these mentioned above, salmonella will be reduced to undectectable numbers in $5-6 \mathrm{~h}$ in slurry digested anaerobically at $53-56^{\circ} \mathrm{C}$ provided that the concentrations of salmonellas found in the Danish and British surveys are of general validity.

Ascaris eggs are known to be extraordinarily resistant to environmental influence due to the complex structure of the egg shell (Keller 1951a). Jettmar \& Exner (1951) stated that Ascaris eggs were killed in $5 \mathrm{~min}$ at $55^{\circ} \mathrm{C}$. In a water bath with a temperature of $55^{\circ} \mathrm{C}$ Ascaris suum eggs were killed in $10 \mathrm{~min}$ (Rudolfs et al. 1951). Schaffert \& Strauch (1976) studied rotating aeration (system Fuchs) of pig slurry and found that at $52.5-53^{\circ} \mathrm{C}$ irreversible lethal changes occurred in Ascaris eggs and they concluded that after reaching $55^{\circ} \mathrm{C}$ the slurry was acceptable from a parasitological point of view. Ascaris lumbricoides was killed after $2 \mathrm{~h}$ at $54^{\circ} \mathrm{C}$ in raw sludge and in digested sludge (Keller 1951b). In pig slurry treated aerobically at $55^{\circ}$ unembryonated Ascaris suum eggs did not survive $30 \mathrm{~min}$ and embryonated eggs did not survive 15 min (Burden \& Ginnivan 1978).

Since Ascaris eggs are more resistant to environmental influence than eggs of gastro-intestinal nematodes of cattle (Persson 1974) it must be assumed that anaerobic thermophilic digestion of cattle slurry will rapidly kill eggs and larvae of trichostrongyle nematodes.
The biogas plant in which the experiments were done has a somewhat special technical design. The fresh slurry is pumped to an antechamber and not, as is usually the case, directly to the processing chamber. The vital aspect with this design from the hygienic point of view is that, even though the process is continuous, all of the slurry will be digested at $55^{\circ} \mathrm{C}$ for at least $17 \mathrm{~h}$.

On the basis of these experiments and of the present knowledge of survival of salmonellas and Ascaris eggs in slurry and sludge in high temperatures it can be concluded that thermophilic digestion of manure in a plant giving a temperature of at least $55^{\circ} \mathrm{C}$ and a detention time of $17 \mathrm{~h}$ will give a hygienically acceptable end product with regard to salmonellas and eggs of intestinal parasites.

\section{References}

Baird-Parker AC, Falk LL, Ragotzkie RA: The effect of Water Activity on the heat resistance of heat sensitive and heat resistant strains of Salmonellae. J. Appl. Bacteriol. 1970, 33, 515-522.

Bicknell SR: Salmonella aberdeen infection in cattle associated with human sewage. J. Hyg. (Lond). 1972, 70, 121-126.

Breer $C$ : Freilandbiologie und infektzyklen der Salmonellen. (Environmental biology and infection cycles of Salmonellae). Schweiz. Arch. Tierheilkd. 1981, 123, 89-96.

Burden DJ, Ginnivan MJ: The destruction of pig helminth ova and larvae in a slurry treatment process. Vet. Rec. 1978, 103, 373-381.

Burge WD: Monitoring Pathogen Destruction. Biocycle. 1983, 24, 48-51.

Corry JEL, Roberts TA: A note on the development of resistance to heat and Gamma radiation in Salmonella. J. Appl. Bacteriol. 1970, 33, 733-737.

Edel W, Guinée PAM,Van Schothorst M, Kampelmacher EH: The role of effluents in the spread of Salmonellae. Zentralbl. Bakt. Hyg. I Abt. Orig. 1972, A 221, 547-549.

Edel W, Van Schothorst M, Kampelmacher EH: Epidemiological Studies on Salmonella in a certain Area. I. The presence of Salmonella in man, pigs, insects, seagulls and in foods and effluents. Zen- 
tralbl. Bakt.Hyg. I Abt. Orig. 1976, A 325, 476484.

Edel W, Van Schothorst, M, Van Leusden FM, Kampelmacher EH: The presence of Salmonella in man, insects, seagulls and in foods, choppingblock scrapings from butcher's shops, effluent of sewage treatment plants and drains of butcher's shops. Zentralbl. Bakt.Hyg. I Abt. Orig. 1978, A 242, 468-480.

Enigk $K$ : Destruction of free living stages of parasites in liquid livestock manure. Berl. Muench. Tierärztl. Wochenschr. 1980, 93, 379-384.

Errebo Larsen H, Munch B: Practical application of knowledge on the survival of pathogenic and indicator bacteria in aerated and non-aerated slurry. In: Strauch D (ed.): Hygienic Problems of Animal Manures. Proceedings of a joint workshop, Hohenheim University, Stuttgart, Oct. 1113, 1982, 20-34.

Ginnivan MJ, Woods JL, O'Callaghan JR: Survival of Salmonella dublin in pig slurry during aerobic thermophilic treatment in batch, cyclic and continuous systems. J. Appl. Bacteriol. 1980, 49, 13-18.

Hage L, Brest Nielsen B: Latrinbeholder som årsag till udbrud av kvaegsalmonellose (Night soil as a cause of salmonellonis in cattle). Dansk Vet Tidsskr. 1977, 60, 657-659.

Hess E, Breer C: Epidemiology of Salmonellae and fertilizing of grasland with sewage sludge. Zentralbl. Bakt. Hyg. I Abt. Orig.1975, B 161, 54-60.

Jack EJ, Hepper PT: An outbreak of Salmonella Typhimurium infection in cattle associated with the spreading of slurry. Vet. Rec. 1969, 84, 196-199.

Jettmar HM, Exner H: Thermoresistenzversuche an Ascaris- und Trichuris-Eiern. (Experiments on the thermoresistance of Ascaris- and Trichuris eggs.) Archiv für Hyg. Bakt. 1951, 134, 173-186.

Jones PW, Matthews RRJ: Examination of slurry from cattle for pathogenic bacteria. J. Hyg. (Lond). 1975, 74, 57-64.

Jones PW Bew J, Burrows MR, Matthews PRJ, Collins $P$ : The occurrence of Salmonellas, mycobacteria and pathogenic strains of Eschericia coli in pig slurry. J. Hyg. (Lond). 1976, 77, 43-50.

Keller P: A review of the literature pertaining to the occurrence and viability of parasitic ova and cysts in sewage, with special reference to Ascaris lumbricoides. Institute for Sewage Purification. Journal and Proceedings. 1951, 1, 92-99.

Keller $P$ : The influence of heat treatment on the ova of Ascaris lumbricoides in sewage. Institute for
Sewage Purification. Journal and Proceedings. 1951, 1, 100-109.

Lee WH, Riemann H: The Inhibition and Destruction of Enterobacteriaceae of Pathogenic and Public Health Significance. In: Hugo WB (ed.): Inhibition and Destruction of the Microbial Cell. Academic Press, London, 1971, 399-418.

Linklater KA, Graham MM, Sharp JCM: Salmonellae in sewage sludge and abattoir effluent in south-east Scotland. J. Hyg. (Lond). 1985, 94, 301-307.

Liu TS, Carlson VL, Snoeyenbos GH: Thermal resistance of smooth and rough derivates of Salmonella Senftenberg 775 W. Poult. Sci. 1968, 47, 1155-1162.

Munch B, Schlundt J: On the reduction of pathogenic and indicator bacteria in animal slurry and sewage sludge subjected to anaerobic digestion or chemical disinfection. In: Strauch D (ed.): Hygienic Problems of Animal Manures. Proceedings of a joint workshop, Hohenheim University, Stuttgart, Oct. 11-13, 1982, 130-149.

Persson L: Parasitogy och larvers överlevnad i gödsel, jord och foder; en litteraturöversikt. (The bionomics of parasite eggs and larvae in manure, soil and fodder: a literature review). Nord. Vet. Med. 1974, 26. Suppl. IV. 1-24.

Rudolfs W, Falk LL, Ragotzkie RA: Contamination of vegetables grown in polluted soil. V. Helminthic contamination. Sewage Industr. Wastes. 1951, 23, 853-860.

Schaffert $R$, Strauch $D$ : The rotating aeration (System FUCHS) for treatment of liquid animal and municipal wastes. 5. Report: Investigations on the disintegration of eggs from Ascaris suum in slurry from pigs and municipal sewage sludge. Berl. Muench. Tierärztl. Wochenschr. 1976, 89, 399-402.

Schlundt J: Sygdomsfremkaldende tarmbakteriers overlevelse i biogasanlaeg og på gyllebehandlede marker. (Survival of pathogenic intetinal bacteria in biogas plants and in slurry contaminated fields). Vet. med. diss. Copenhagen, 1982.

Strauch D: Hygienische Probleme bei der Gewinnung, Behandlung und Verwertung tierischer Exkremente. (Hygienic problems of the production, treatment and utilization of animal faecal wastes.) In: Strauch D, Baader W, Tietjen C: Abfälle aus der Tierhaltung. (Animal faecal wastes.) Verlag Eugen Ulmer, Stuttgart, 1977, 246-252. 


\section{Sammanfattning \\ Överlevnad av salmonellabakterier och Ascaris suum ägg $i$ en termofil biogasanläggning.}

Anläggningen mottog gödsel från 200 mjölkkor och 400 ungdjur. Bakterierna och parasitäggen förvarades i filterpåsar i gödseln, vilken hade en temperatur på $55^{\circ} \mathrm{C}$. Inga viabla salmonellabakterier eller $A s$ caris suum ägg kunde påvisas efter 24 timmars uppehåll i rötningskammaren. Överlevnaden av salmonellabakterier och $A$. suum ägg undersöktes även i slutförvaringsbassängen till vilken gödseln pumpades efter rötningen. Gödseltemperaturen i slutförvaringsbassängen varierade mellan 22 och $27^{\circ} \mathrm{C}$. Salmonellabakterierna överlevde 35 men inte 42 dygn. $60 \%$ av $A$. suum äggen var viabla på dag 56 vid vilken försöket avbröts.

(Received September 12, 1993; accepted October 26, 1994).

Reprints may be requested from: L. Plym-Forshell, Department of Animal Hygiene, Faculty of Veterinary Medicine, Swedish University of Agricultural Sciences, P.O. Box 345, S-532 24 Skara, Sweden. 
